\title{
English summaries / Danske resuméer
}

\author{
Praising the Pagan Gods: Grundtvig's Civil Religious Poetization of \\ the Pagan Past
}

Sophie Bønding

"Thor lever endnu og ager i Sky": Grundtvigs civilreligiøse poetisering af den hedenske fortid

N.F.S. Grundtvig betragtes ofte som både kirkefader for den danske kirke og grundlægger af den danske nation. Hans sideløbende interesse for fællesskabsdannelse og social sammenhængskraft i det kirkelig-religiøse fællesskab og i det nationalt-sekulære fællesskab er alment kendt og del af en forskningsmæssig diskurs om Grundtvig. Alligevel er paralleliteten i hans tænkning omkring de to sfærer generelt underbelyst. Formålet med nærværende artikel er at kaste lys over dette. Under anvendelse af det religionsvidenskabelige begreb civilreligion samt forskellige religionsteorier vises det, hvordan Grundtvigs ambitioner for og konkrete brug af nordisk mytologi i den nationalt-sekulære sfære af dansk samfundsliv var afgørende influeret af underliggende religiøse antagelser og tænkemåder. Dette kommer til udtryk blandt andet i Grundtvigs udlægninger af nordisk-mytologiske fortællinger og figurer ved hjælp af eksegetiske strategier hentet fra bibelsk eksegese. Med fokus på Brage-Snak-forelæsningerne (1844) argumenteres der for, at Grundtvig behandlede nordisk mytologi som et slags "civilreligiøst helligskrift" ved at udlægge og aktualisere mytologien på samtidsanliggender, der havde med den sekulære sfære at gøre. Således synes Grundtvig at have forsøgt at skabe, hvad man kan kalde en "civilreligiøs vækkelse" med det formål at lade nordisk mytologi indgå som en del af danskernes levende, mundtlige kultur efter den overbevisning, at det ville indsætte nordisk mytologi som fundamentet for en kollektiv selvbevidsthed og et dansk-nationalt fællesskab. Som led heri synes Brage-Snak-foredragene som rituelle begivenheder at have udgjort konkrete forsøg fra Grundtvigs side på at vække en autentisk dansk verdensanskuelse og et autentisk dansk etos i den forsamlede flok, således at 
disse kunne smelte sammen og få indvirkning på deltagernes samfundsliv i dagligdagen.

Grundtvig and John Wesley - A Study of the Convergence in Their
Theology

\section{Jorgen Thaarup}

Grundtvig og John Wesley - En undersøgelse af de konvergerende træk i deres teologi

Artiklen handler om de konvergerende træk, man finder hos John Wesley (1703-91) og N.F.S. Grundtvig (1783-1872) - to markante fornyere af reformationens teologi i perioden 1740-1850. Tesen er, at det er forbindelsen til den antikke østlige teologi og liturgi, som kan forklare de konvergerende træk. Artiklen behandler dog kun et enkelt ud af ni temaer fra afhandlingen Med venner $i$ lys vi tale (andet oplag 2020), hvor sammenligneligheden er tydelig, nemlig: "Hvad Kristus har gjort som grundlag for menneskets frelse." Inspirationen fra den østlige teologi hentes for Grundtvigs vedkommende i Irenæus' skrifter og den græsk ortodokse liturgi, mens Wesley trækker på Makarios Homilier, Efraim Syreren og den Apostolske Konstitution. Fælles var de dog om inspiration fra Exeterbogen, Beda og den østlige liturgi, som angelsakserne fortsatte med at bruge lang tid efter latiniseringen af kirken i Britannien og giver yderligere forklaring på de konvergerende træk. 


\section{Grundtvig som stridsmand og polemiker}

\section{Vanja Thaulow}

\section{Grundtvig as Polemicist and "Warrior of God"}

The article summarizes the main points from the $\mathrm{PhD}$ thesis, titled Warrior of God. Rhetorical Criticism of N.F.S. Grundtvig's Early Polemical Writings on Theology (1810-1825). The study has been carried out as a series of rhetorical close readings of selected polemical works (sermons, speeches, history writing, and pamphlets) with special focus on the author's self-representation, audience construction, argumentation, and style. The analyses show that Grundtvig's early works are marked by a self-representation as a prophet of doom, a parrhesiast, and a "warrior of God." Grundtvig speaks from an exalted position, almost from God's perspective. This position results in an asymmetrical relationship to the audience. He treats readers as if he can force them into thinking and believing in a certain way. Characteristic of his argumentation is the use of postulates, arguments from authority, and motivation by fear. In personal polemical encounters, Grundtvig even proceeds in an eristic manner, resorting to stratagems such as arguments ad hominem. His style can be described in classical terms, as asperous and vehement (cf. Hermogenes' On Types of Style) and, in modern terms, as polemical and provocative. The study concludes that Grundtvig's sermons, speeches, and scientific works are extraordinarily polemical in the years 1810-1825. Audiences' reactions clearly show that he violated genre conventions time and again. Most people reacted with shock and indignation to his hate speech. Grundtvig's polemical style attracted a lot of attention - some of his books became regular succès de scandale - but he did not convince many people of his views. Later in his life, Grundtvig changed strategies. He took leave of the strict biblical and dualistic theology and realized that engaging in controversies would not contribute to his overall aim which was the religious revival of the Danish people. His belligerence subsided but never disappeared completely. 


\section{En udeladelse}

\section{Flemming Lundgreen-Nielsen}

\section{An Omission}

This article discusses why in Udvalgte Skrifter (Selected Writings) volume 5 (1905), in his edition of Nordens Mythologi (Norse Mythology) 1832, Holger Begtrup omitted the last fourteen lines of Grundtvig's brief chapter on "The springs of Urda and Mimir." Begtrup's edition is otherwise excellent and reliable. It is suggested that Begtrup deleted this particular concluding section praising secular world history because he might have missed a Christian line of religious reasoning in it. 